\title{
Differences in the Determinants and Targeting of Antidumping: China and India Compared
}

\author{
Ning Meng ${ }^{\mathrm{a}}$, Chris Milner ${ }^{\mathrm{b}}$ and Huasheng Song ${ }^{\mathrm{a}}{ }^{1}$ \\ ${ }^{\text {a }}$ College of Economics, Zhejiang University, Hangzhou, 310027, China \\ ${ }^{\mathrm{b}}$ School of Economics, University of Nottingham, Nottingham, NG7 2RD, UK.
}

Running title : Comparative Analysis of Antidumping Filings between China and India

\begin{abstract}
Despite both being developing countries, China and India have markedly contrasting patterns in their use and targeting of antidumping (AD) measures. We explore the factors driving $\mathrm{AD}$ use by these two countries, considering in turn macroeconomic, strategic and other determinants. We find more regular or systematic features of AD use by China, while India displays a less systematic pattern of AD use. Economic growth, AD club effect and FTA participation are shown to constrain AD use by China. Compared to India, AD use by China is also more sensitive across industries. Furthermore, China targets developed countries more than developing countries, while India is less discriminating with respect to the country type it targets.
\end{abstract}

Keywords: China; India; antidumping

JEL:C33,F13; P51

\section{Introduction}

Since the late 1980s, especially followingthe establishment of the WTO in 1995, antidumping (AD) filings have been growing rapidly and evolved into global phenomenon. Initially traditional users like the United States (US) and European Union (EU) accounted for most of AD filings, butincreasingly emerging economies are becomingheavy AD users. India (IND), Argentina (ARG), Brazil (BRA), China (CHN), South Africa (ZAF) and Turkey (TU) have become the major AD users globally, having initiated 43\% of the total AD cases filed between 1995 and 2014.Emerging economies have gradually become dominant in the global AD use. Nowadays, AD is not only a

\footnotetext{
${ }^{1}$ Corresponding author. Email: songzju @zju.edu.cn. Support from Chinese Ministry of Education (10JJD790030), Hengyi Foundation and CSC are gratefully acknowledged.
} 
major trade issue between the North and the South, but also an increasingly significant one in the South-South trade. ${ }^{2}$

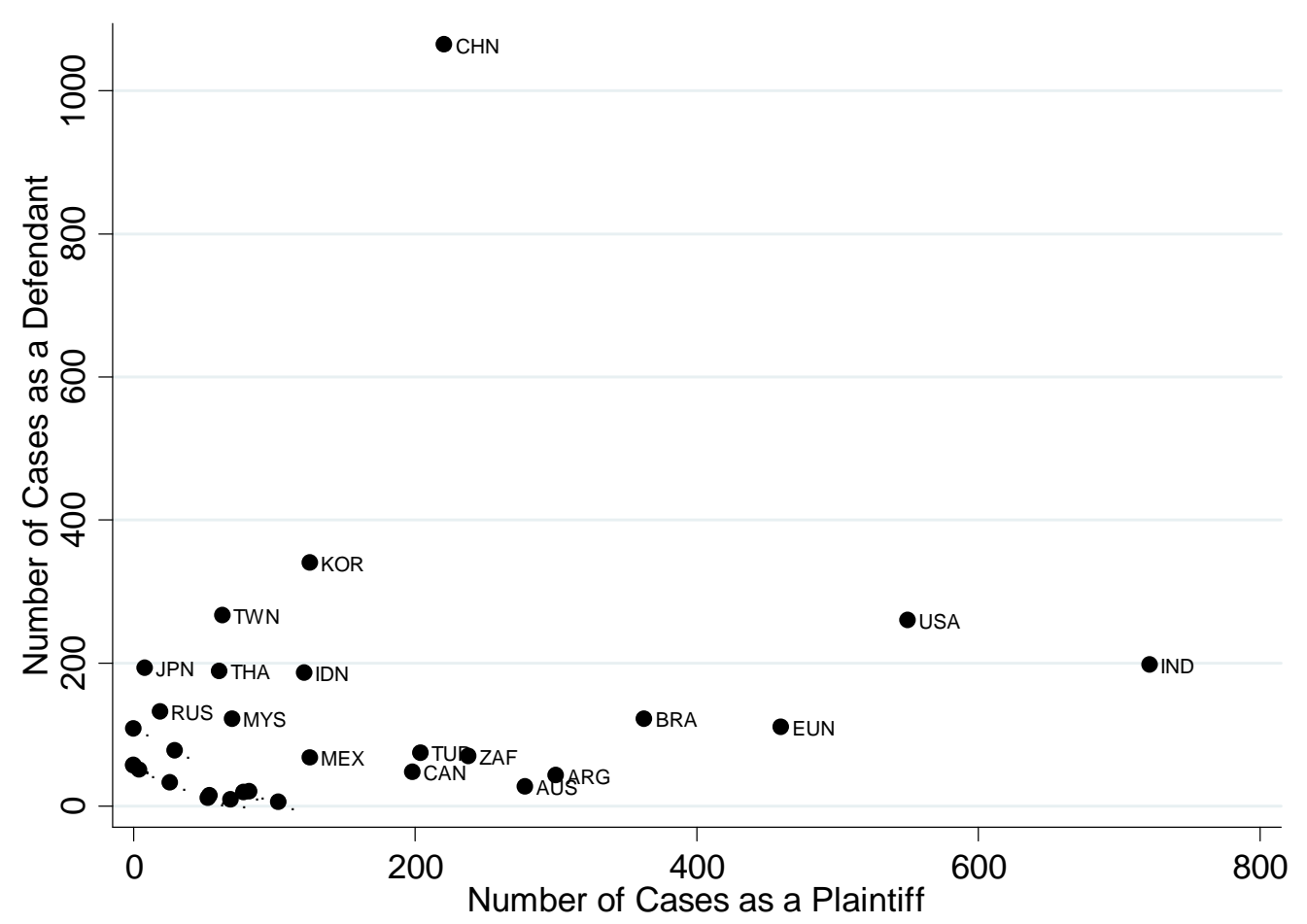

Figure 1. Asymmetry for a Country as a Plaintiff and as a Defendant during 1995-2014

As typical emerging economies and new AD users, China and India both play a significant role in $\mathrm{AD}$ proliferation globally. However, there are distinctive differences in $\mathrm{AD}$ patterns between the two countries. China, the world's largest AD target, faced 1064 AD investigations and initiated 221 AD investigations from 1995 to 2014. In contrast, as the heaviest AD user in the world, India launched $722 \mathrm{AD}$ investigations and was subject to $198 \mathrm{AD}$ investigations during the same period. Thus, there exists asymmetry between China and Indiain their roles as a plaintiff and as a defendant with respect to other countries (see Figure 1). As a developing country and new AD user, India in contrast to China has an $\mathrm{AD}$ pattern more consistent with developed countries such as the US and the EU. But both China and India, as large developing countries, are considered similar in many ways. ${ }^{3}$ They both reformed their inward trade policies: China began its reform and opening up in 1978, while India also began a series of trade liberalization reforms in 1991. Why then are their patterns of AD use so different? What factors drive emerging economies' heavy use of $\mathrm{AD}$ in recent years? This paper will examine determinants of $\mathrm{AD}$ use in emerging

\footnotetext{
2 There is a substantial literature concerned with analysing the trade and/or welfare effects of AD measures, including China (e.g. Park, 2009). This paper is concerned with the political economy motives for adopting these particular trade policy measures.

3 There are of course important differences in the pattern of production and export specialisation in the two countries (Lo and Liu, 2009). This may account in part for some of the differences in AD usage and targeting between the two countries that we find in this study.
} 
economies with China and India as representatives and analyze the differences between the two countries.

The rest of the paper is organized as follows. Section 2 provides an overview of the factors affecting $\mathrm{AD}$ use that have been identified in the literatures. Section 3 describes the methodology and data used in this study, while Section 4 describes the empirical findings. Concluding remarks are provided in Section 5.

\section{Overview of Factors Affecting AD Use}

\section{Macroeconomic determinants of antidumping}

The influence of the importing country's macroeconomic conditions on AD use has been identified by several studies (Knetter and Prusa, 2003; Feinberg, 2005; Blonigen, 2006; Francois and Niels, 2006; Moore and Zanardi, 2009; Bao and Qiu, 2011). One major finding is that more $\mathrm{AD}$ filings are to be expected with slower domestic economic growth. However, no consistent argument is to be found in the literature on the effect of the real exchange rate between the importing and exporting countries' currencies on AD activity. Feinberg (1989) finds that the US dollar depreciation was accompanied by increased AD cases brought by the US, while Francois and Niels (2006) and Vandenbussche and Zanardi (2008) find no statistically significant effect of the real exchange. However, most studies argue that the importing country' s currency appreciation will lead to more AD filings (Feinberg, 2005; Irwin, 2005; Blonigen, 2006; Mahand Kim, 2006; Francois and Niels, 2006). Additionally, Blonigen and Bown (2003), Blonigen (2006), Irwin(2005), Mah and Kim (2006)find that an increase in the import penetration ratio has a positive and statistically significant impact on AD filings, but the studies of Leidy (1997) and Sadni-Jallab et al. (2006) find that such effect is generally statistically insignificant.

In addition to the main macroeconomic conditions mentioned above, trade liberalization is also a determinant worth considering though there is only a small but growing literature on the relationship between AD use and trade liberalization (Moore and Zanardi, 2011). However, the nature of the relationship is subject to some ambiguity. On the one hand, Feinberg and Reynolds (2006) argue that trade liberalization, and the associated lowering of traditional sources of protection, has been associated with increased $\mathrm{AD}$ use in some developing countries. Similarly, Bown and Tovar (2011) conclude that Indian trade liberalization efforts may have increased the probability of AD filings. Moore and Zanardi (2011) also identify a similar relationship. But Finger and Nogués (2005), who analyze the role of AD and safeguard actions in Latin American countries undergoing trade liberalization, conclude that such measures were a useful tool in dealing with protectionist pressures and may therefore have facilitated the adoption of traditional trade reforms such as tariff reduction. 
In terms of macroeconomic conditions both in the exporting and importing countries, Bown and Crowley (2013) estimate the impact of macroeconomic fluctuations on import protection policies before and during the Great Recession. They support the view of Bagwell and Staiger (1990, 2003) that temporary trade barriers increase when macroeconomic conditions in both the importing country and exporting country are weak. Crowley (2010), who investigates the same issue using product level data, also finds that import restrictions increase in response to macroeconomic weakness abroad. Similarly, Bown and Crowley (2014) find that the impact of macroeconomic shocks on trade policy is similar in emerging economies to those for developed countries.

\section{Strategic determinants of antidumping}

In addition to macroeconomic factors, Prusa and Skeath $(2002,2004)$ explore the impact of strategic factors on $\mathrm{AD}$ use, finding that the importing countries may also consider how their trading partner may react when imposing its own trade protection. They identify that both retaliatory AD use of the "tit-for-tat" kind and "country club effects" prevail. Moreover, the strategic motives of traditional $\mathrm{AD}$ users are shown to be different from that of new $\mathrm{AD}$ users. Blonigen and Bown(2003) find that strategic considerations, in particular the share of US exports in the potential target country, can influence the decision by the US to file an AD case. Aggarwal (2004), Feinberg and Reynolds (2006) also find a positive relationship between retaliation and AD filings. Dong (2013) argues that the underlying reasons for AD should be strategic in nature, in particular, retaliatory.

In addition to retaliatory factors, strategic determinants include the spread of $\mathrm{AD}$, namely a contagion effect (Bao and Qiu, 2011). Bown and Crowley (2006) consider how AD by the US against Japanese exports affected third markets through trade deflection, which raises the probability of trade protection by other countries. Feinberg and Reynolds (2006) consider both retaliatory factors and trade deflection among sets of countries. They find that deflection has an impact on both new and traditional users, but retaliation is mainly adopted by new AD users. Moore and Zanardi (2011) also provide evidence of retaliation and deflection effects as determinant of AD filings. Bao and Qiu (2011) further distinguish a deflection effect from an "echo effect" in both the US and China AD filings, with the latter tending to cause these countries to launch more $\mathrm{AD}$ filings against countries that are already receiving $\mathrm{AD}$ filings from elsewhere.

\section{Other determinants of antidumping}

The proliferation of free trade agreements (FTA) since the 1990s has provoked interest in the effects of this on AD use. On the one hand, FTAs may increase a country's AD filings to protect domestic industries from the increased imports from FTA sources. On the other, FTAs 
may impose new disciplining mechanismswhich reduce the use of $\mathrm{AD}$ in order to promote intra-FTA trade (Ahn and Shin, 2011).

Although the literature has focused traditionally on the $\mathrm{AD}$ use of developed countries like the US and the EU, there are a few studies on global antidumping patterns (Prusa, 2001; Feinberg and Reynolds, 2006) and increasingly studies are also considering developing countries (Moore and Zanardi, 2009; Bown and Tovar, 2011; Zeng, 2011). As for comparative studies, Aggarwal (2004) compares the $\mathrm{AD}$ determinants of developed and developing countries. Meanwhile, Sadni-Jallab et al. (2006) study AD filings by comparing the US and the EU, and Bao and Qiu (2011) compare China and the US, focusing on whether China is more retaliatory than the US. We are the first to focus on comparative study about two representatives of emerging economies and provide evidence of most comprehensive determinants of $\mathrm{AD}$ use.

As for studies focusing on China, the majority focuses on why China is targeted (see Wang and Xie, 2009; Bao, 2011; Zhang and Xie, 2011) rather than why it targets others. Although there are some articles on India, for example Bown and Tovar (2011) on the effect of trade liberalization on AD, the coverage of the existing literature is limited. Yang and Yao (2012) compare China and India, but concentrate on providing a statistical summary of the facts of AD activity in the two countries.

There is a large existing, empirical literature on the political economy, determinants of $\mathrm{AD}$ use. This literature has shown that there are systematic macroeconomic and strategic factors that fashion $\mathrm{AD}$ use. Most work has been done on the industrial, rather than developing, countries, and there is relatively little cross-country, comparative analysis, especially between developing countries. There is also relatively limited work for developing countries based on data that allows analysis of AD use by target country at the industry level. In this paper, we seek to extend on this literature. We examine what macroeconomic, strategic and other factors influence $A D$ use in China and India using a broad set of explanatory variables, and using a newly available dataset which allows country-industry level analysis.

\section{Empirical strategy and data}

\section{The model and methodology}

Following our discussion of the related literature in the preceding section, we propose the following benchmark model of the determinants of $\mathrm{AD}$ use:

$$
A D_{i j t}=a_{0}+\alpha^{\prime} * m_{i j t}+\beta^{\prime} * s_{i j t}+\gamma^{\prime} * c_{i j t}+\epsilon
$$

where the dependent variable $A D_{i j t}$ is a binary variable indicating whether country $i$ initiated $\mathrm{AD}$ filings against country $j$ in year $t$, or count variable indicating the total number of AD filings by country $i$ against the imports from country $j$ in year $t, m_{i j j}$ is a vector of macroeconomic variables, 
$s_{i j t}$ is a vector of strategic variables and $c_{i j t}$ is a vector of other variables. Vectors $\alpha, \beta, \gamma$ are regression coefficients, while $t$ is time trend and $\varepsilon$ is the error term. When we use the dummy as the dependent variable, we estimate a probit model. For the number of AD filings as the dependent variable, we employ a count model to analyze the data.

\section{Data and variable definitions}

Vector M (macroeconomic variables)

$\mathrm{GDP}_{\mathrm{it}-1}$ : Importing country $i$ 's real GDP growth rate in year $t-1$. If growth is relatively slow, domestic firms are more likely to turn to protectionist measures including AD filings to constrain foreign sales. In recession conditions, foreign firms have incentives to cut prices to maintain export volumes, which increases the probability of an affirmative material injury finding by the $\mathrm{AD}$ initiators. This suggests that slow growth in the importing country may cause an increase in its AD filings.

$\mathrm{TAR}_{\mathrm{it}-1}$ : Importing country $i$ 's trade weighted average applied tariff rate in year $t-1$. In the process of trade liberalization, tariff reduction may induce national governments to impose AD duties as a substitute for tariffs. Thus, AD filings by the importing country may increase with the lowering of tariffs.

$\mathrm{STR}_{\mathrm{it}}$ : The ratio of industrial value-added to GDP of importing country $i$ in year $t$. Products involved in $\mathrm{AD}$ cases are mainly industrial products, so $\mathrm{AD}$ activity is likely to be influenced by industrial development. An increase in industrial ratio, which may indicate industrial development and more internationally competitive industrial products, leads to less use of $\mathrm{AD}$ filings. At the same time, a decrease in the industrial ratio indicates a less competitive industry, which will be more vulnerable to the impact of imported products. Domestic firms may be more likely to request for protection in this situation. Therefore, the influence of the industrial ratio on AD filings is expected to be negative.

DEP $_{\mathrm{it}}$ : The ratio of the trade volume to GDP of importing country $i$ in year $t$ captures the dependence of a country's economy on trade. On the one hand, a higher import ratio motivates a country to protect domestic firms, which leads to more AD use. On the other hand, a higher export ratio and the more dependent the country is on outside world, and the greater the government's incentive is to maintain mutually favorable trading partnerships. We assume therefore that greater export dependence constrains the use of $\mathrm{AD}$ filings. Therefore, the influence of the trade dependence on $\mathrm{AD}$ use is ambiguous a priori.

FGDP $_{\mathrm{jt}-1}$ : Exporting country $j$ 's real GDP growth rate in year $t-1$. Most existing studies focus on the impact of the importing countries' macroeconomic conditions; few studies consider those conditions of exporting countries. In view of systematic effects of the global economy, we also 
consider the potential effect of the exporting country's GDP growth, assuming that AD filings may increase as result of a decrease in the exporting countries' GDP growth, following Bown and Crowley (2013).

$\mathrm{EX}_{\mathrm{ijt}-1}$ : The percent change of real exchange rate between country $i$ and country $j$ in year $t-1$. Domestic firms' competiveness with respect to imports will be weakened by an appreciation of the home country's currency and tend to increase pressures for protection. Furthermore, since the price of the exporting countries' products will fall due to such changes in the exchange rate, it is easier to prove a material injury. Therefore, the effect of currency appreciation on $\mathrm{AD}$ filings is expected to be positive.

IMP $_{\mathrm{ijt}}$ : Bilateral import penetration ratio of country $i$ 's imports from country $j$. It is defined as the ratio between the value of bilateral imports as a percentage of total domestic demand, where the domestic demand is the GDP minus exports plus imports. This bilateral import penetration ratio reflects the degree of competitive pressure from the specific exporting country. Thus, when the ratio increases, domestic firms are expected to seek more protection against imports from this source, causing the use of $\mathrm{AD}$ to increase.

Vector $S$ (strategic variables)

$\mathrm{TFT}_{\mathrm{ijt}-1}$ : The total number of AD filings initiated by country $j$ against country $i$ in year $t-1$. This variable is used to capture the "tit-for-tat" retaliation proposed by Prusa and Skeath (2004).

RET $_{\mathrm{it}-1:}$ The total number of AD initiated by all other countries against country $i$ in year $t-1$. This variable is included to capture the incentive in country $i$ for a general level of retaliation. The importing country is more likely to initiate $\mathrm{AD}$ against other countries when targeted by other countries in previous year. We expect an increase in RET to increase AD filings by country $i$.

CLUB $_{\mathrm{jt}-1}$ : The total number of AD made by country $j$ against all countries in year $t-1$. This indicates whether country $j$ is a heavy user of $\mathrm{AD}$ filings, i.e. an $\mathrm{AD}$ club member. If it is, there will be two effects on country $i$ 's AD use. On the one hand, country $i$ may reduce AD against country $j$ for fear of retaliation (Feinberg and Reynolds, 2006). On the other hand, as an AD club member, country $j$ is more likely to be targeted, a result captured by the "AD club" effect (Prusa and Skeath, 2004). Therefore, the influence of CLUB is ambiguous.

$\mathrm{DEFL}_{\mathrm{jt}-1}$ : The total number of AD against country $j$ by all countries except for country $i$ in year $t-1$ is used to proxy the "deflection" effect. Cases filed against country $j$ may divert its trade flows elsewhere and cause import surges in third countries including country $i$, leading to an increase in AD by these countries. We expect an increase in DEFL to increase AD by country $i$.

$\mathrm{ECHO}_{\mathrm{jt}}$ : The total number of AD against country $j$ by all countries except for country $i$ in year $t$ is used to measure the "echo" effect. AD against country $j$ 's exports by other countries will increase 
the incentive to file $\mathrm{AD}$ cases by firms in country $i$, since it increases these firms' expectation of affirmative determination by the government when AD filings are made. Such behavior is associated with information transmission of AD fillings across the parties involved (Bao and Qiu, 2011).

Vector $C$ (other variables)

FTA $_{\mathrm{it}}$ : The number of FTAs country $i$ has signed up to year t. As previously mentioned, FTAs have two conflicting effects on AD filings (Ahn and Shin, 2011) and the net effect is uncertain.

REC: Dummy variable of the global economic recession, the value of this variable is 1 from 2008 to 2014 and 0 before 2008. We introduce the variable to exam what impact global economic recession has on the AD filings of China and India. Theoretically, countries are more likely to turn to protectionism during economic recession.

\section{Data sources and estimation method}

This study intends to analyze the motives of AD filings in China and India. Our sample consists of panel data from 1997 to 2014 for China and from 1992 to 2014 for India. ${ }^{4}$ In order to capture the changes of trade policy in India since the liberalization reforms in 1991, we employ a different sample period for India than for China. But we also match them consistently when the data are pooled together. For the dependent variable, we use the Global Antidumping Database constructed by Chad Bown. In addition to the dependent variable, the retaliatory variables are constructed by organizing bilateral $\mathrm{AD}$ filing data based on that database.

The macroeconomic variables (real GDP growth rate, ratio of industrial value-added to GDP, ratio of trade volume to GDP) are obtained from the World Bank's World Development Indicators. Data on trade weighted average tariff rates is constructed from the World Integrated Trade Solution (WITS). Data on bilateral trade comes from the United Nations Commodity Trade Statistics Database (COMTRADE). Data on FTAs is from the Regional Trade Agreements Information System (RTA-IS).

$\mathrm{AD}$ cases are discrete data, which can be measured or summarized in incidence terms $(0,1$ binary dummy variable) or in extent terms by counting the number of cases. We use both measures here. For the binary variable measure we estimate a probit model. For the count measure the widely used nonlinear model is the Poisson model. This, however, requires that the variance of the relevant variable should not exceed its mean, otherwise over-dispersion occurs and the Poisson estimator is inconsistent, in which case the negative binomial model (NBM) performs better. We employ Cameron and Trivedi's (1990) methods to detect over-dispersion. In

\footnotetext{
${ }^{4}$ The countries constitute the sample of estimation purpose include all the countries with records of antidumping by China and India in the Global Antidumping Database (GAD) maintained by the World Bank during sample period (see http://econ.worldbank.org/ttbd/gad/).
} 
accordance with the results of tests for over-dispersion, we use the NBM model for both China and India. We use the maximum likelihood techniques and capture the (exporting) country fixed effects through the panel data. ${ }^{5}$.

\section{Summary data}

The variable definitions, descriptive statistics and expected sign are summarized in Table 1, while the relationships between macroeconomic conditions of the importing country and AD filings in China and India are separately shown in Figure 2 and Figure 3. There are obvious differences in macroeconomic conditions between China and India. The real GDP growth rate (denoted by GDP in the figures) of China is higher and less volatile than India's over the period 1997-2014, while the magnitude of tariff reduction (denoted by TAR in the figures) in India is much larger than in China. In addition, the industrialization level (proxy for industrial structure) (denoted by STR in the figures) and trade dependence (denoted by DEP in the figures) in China are higher than in India.

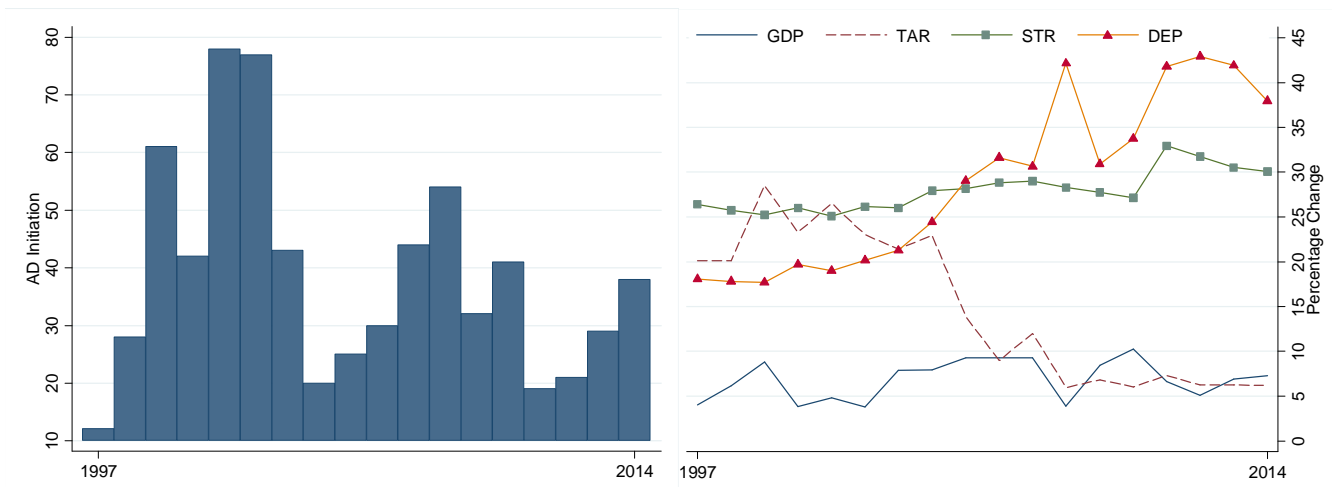

Figure 2. Relationship between Macroeconomic Variables and China's AD Filings (1997-2014)
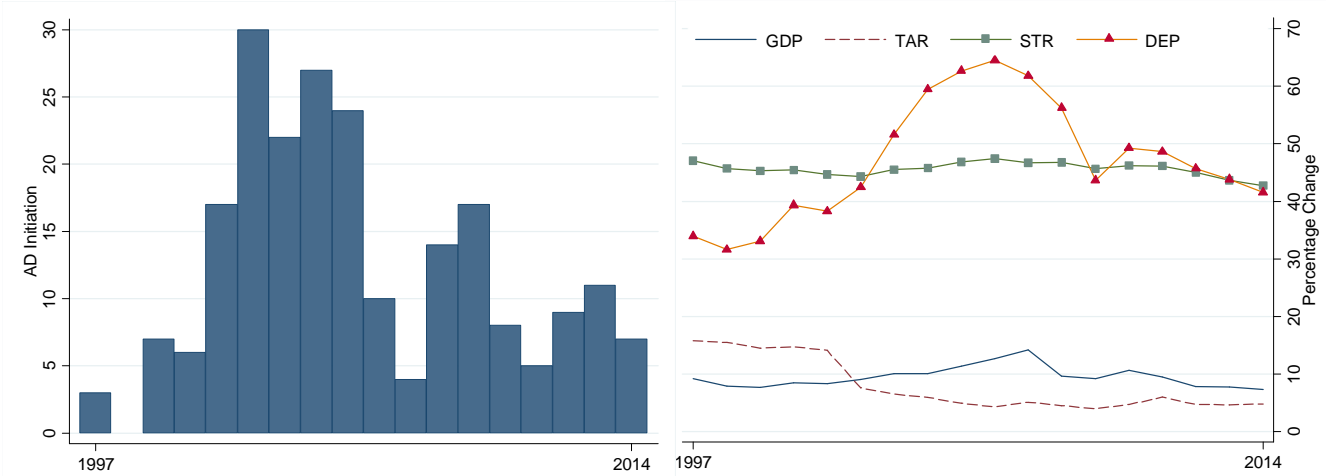

Figure 3. Relationship between Macroeconomic Variables and India's AD Filings (1997-2014)

\footnotetext{
${ }^{5}$ Given that our data may also contain an excessive number of zeros, we also investigate the use of a zero-inflated, negative binomial model as part of the robustness analysis.
} 
Table 1. Variable Description, Summary Statistics and Expected Sign

\begin{tabular}{|c|c|c|c|c|c|c|c|}
\hline \multirow{2}{*}{\multicolumn{2}{|c|}{ Variable }} & \multirow[b]{2}{*}{ Variable Definition } & \multicolumn{2}{|c|}{ China } & \multicolumn{2}{|c|}{ India } & \multirow{2}{*}{$\begin{array}{l}\text { Expected } \\
\text { Sign }\end{array}$} \\
\hline & & & Mean & $\begin{array}{l}\text { Std. } \\
\text { Dev. }\end{array}$ & Mean & $\begin{array}{l}\text { Std. } \\
\text { Dev. }\end{array}$ & \\
\hline \multirow{2}{*}{$\begin{array}{l}\text { Dependent } \\
\text { Variable }\end{array}$} & $\begin{array}{l}\text { Dummy of } \\
\mathrm{AD}_{\mathrm{ijt}}\end{array}$ & Dummy for AD initiation & 0.25 & 0.43 & 0.24 & 0.43 & --- \\
\hline & Count of $\mathrm{AD}_{\mathrm{ijt}}$ & Count of $\mathrm{AD}$ cases & 0.45 & 1.04 & 0.54 & 1.47 & --- \\
\hline \multirow{7}{*}{$\begin{array}{c}\text { Macroeconomic } \\
\text { Variable }\end{array}$} & $\mathrm{GDP}_{\mathrm{it}-1}$ & Lag of eal GDP growth rate & 9.62 & 1.72 & 6.77 & 1.96 & - \\
\hline & $\mathrm{TAR}_{\mathrm{it}-1}$ & Lag of tariff rate & 8.71 & 5.15 & 20.74 & 13.62 & - \\
\hline & $\mathrm{STR}_{\text {it }}$ & Industrial structure & 45.6 & 1.18 & 27.60 & 2.08 & - \\
\hline & $\mathrm{DEP}_{\text {it }}$ & Trade dependence & 47.08 & 10.14 & 26.19 & 9.70 & $?$ \\
\hline & FGDP $_{\mathrm{jt}-1}$ & $\begin{array}{l}\text { Lag of foreign real GDP } \\
\text { growth rate }\end{array}$ & 3.16 & 3.51 & 3.22 & 4.54 & - \\
\hline & $\mathrm{EX}_{\mathrm{ijt}}$ & $\begin{array}{l}\text { Percent change of real } \\
\text { exchange rate }\end{array}$ & 2.18 & 11.33 & -0.46 & 5.73 & + \\
\hline & $\mathrm{IMP}_{\mathrm{ijt}}$ & Import penetration ratio & 0.60 & 0.87 & 0.16 & 0.33 & + \\
\hline \multirow{5}{*}{$\begin{array}{l}\text { Strategic } \\
\text { Variable }\end{array}$} & TFT $_{\mathrm{ijt}-1}$ & "tit-for-tat" retaliation & 1.24 & 2.75 & 0.09 & 0.48 & + \\
\hline & $\mathrm{RET}_{\mathrm{it}-1}$ & General retaliation & 54.22 & 15.66 & 9.04 & 3.82 & + \\
\hline & CLUB $_{\mathrm{jt}-1}$ & $\mathrm{AD}$ club & 5.87 & 12.03 & 3.05 & 8.83 & $?$ \\
\hline & DEFL $_{\mathrm{jt}-1}$ & Deflection effect & 4.91 & 5.34 & 3.16 & 6.93 & + \\
\hline & $\mathrm{ECHO}_{\mathrm{jt}}$ & Echo effect & 4.91 & 5.14 & 3.26 & 6.94 & + \\
\hline Other & FTA $_{\text {it }}$ & Free trade agreements & 5.61 & 5.19 & 4.70 & 4.36 & $?$ \\
\hline Variable & $\mathrm{REC}_{\mathrm{t}}$ & The economic recession & 0.39 & 0.49 & 0.30 & 0.46 & - \\
\hline
\end{tabular}

\section{Empirical results}

\section{Comparative analysis of $A D$ determinants for China and India}

The baseline regression results for China and India are reported in Table 2. ${ }^{6}$ We employ a probit model where the AD dummy is the dependent variable and report the marginal effects of each variable. For the number AD cases as the dependent variable, we use a negative binomial model as indicated by the over-dispersion tests. We report the incidence rate ratio (IRR) for ease of interpretation.

\footnotetext{
${ }^{6}$ We also estimated zero-inflated binomial models where the count of AD cases is the dependent variable. The results, which are qualitatively similar to the base results from the standard count model, are not reported but are available from the authors on request.
} 
Table 2. Results for Baseline Estimates for China and India of Determinants of AD Filings

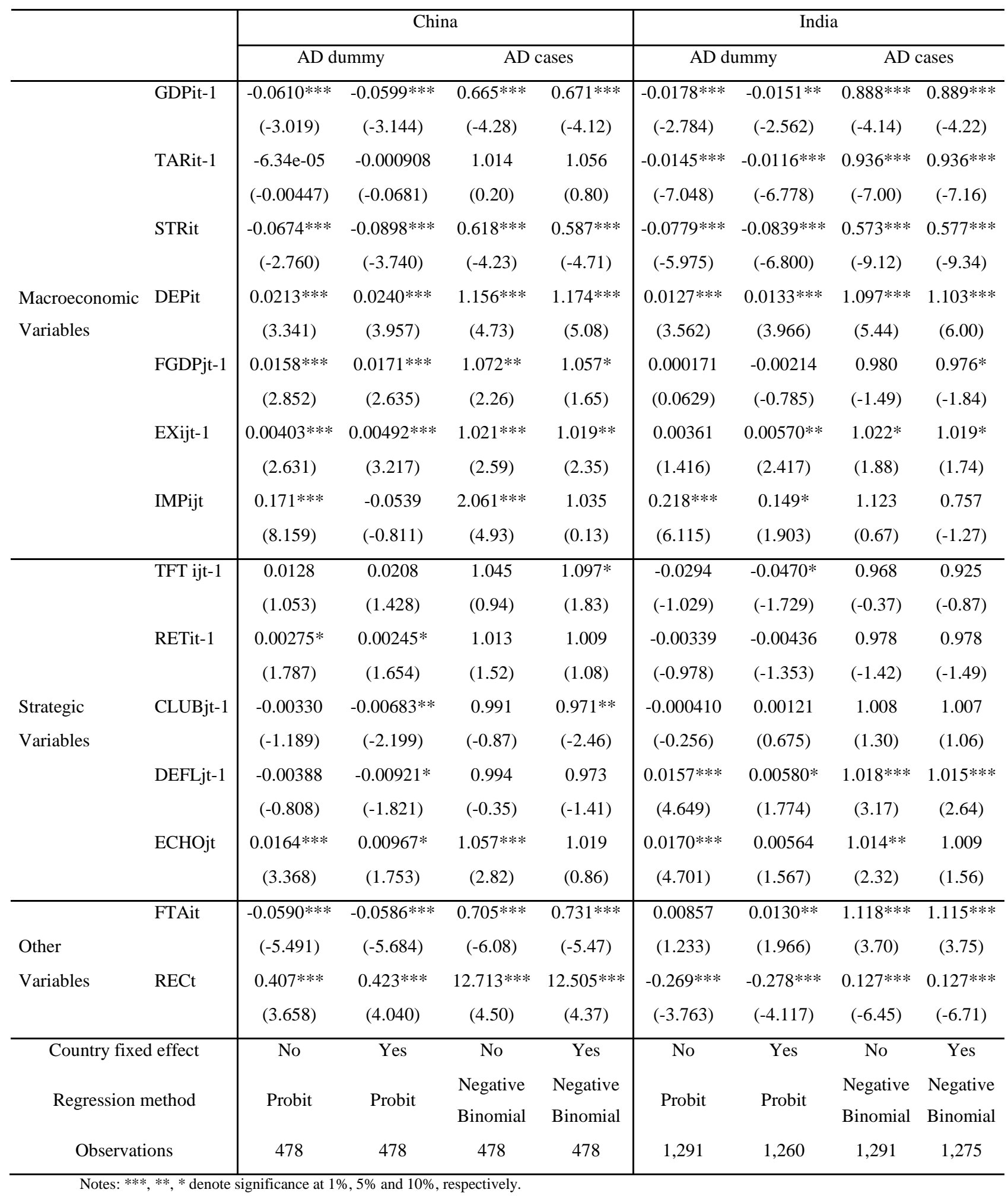

We find that for both China and India an increase in domestic GDP growth will significantly reduce $\mathrm{AD}$ use. The probability of $\mathrm{AD}$ initiation decreases $6 \%$ for China and $2 \%$ for India as their GDP growth rate increases by $1 \%$ in year $\mathrm{t}-1$, while the AD cases decrease by a factor of 0.7 for China and 0.9 for India, respectively. However, a lowering of tariffs in year t-1 significantly 
increases the probability of $\mathrm{AD}$ initiation and the $\mathrm{AD}$ cases only for India. This finding supports the interesting argument about substitution between AD measures and tariffs, especially for India in which tariff decreases dramatically from $56 \%$ in 1992 to $6 \%$ in 2014 since the liberalization reforms in 1991. An increase in industrial ratio significantly reduces AD use both for China and India, while an increase in the trade dependence significantly increases AD use. The former finding is consistent with expectation, while the latter shows that the effect of import dependence dominates.

Table 3. China and India's Integration into the World Economy

\begin{tabular}{c|cc|cc}
\hline \multirow{2}{*}{ Year } & \multicolumn{2}{|c|}{ Share of Global Trade (IM+EX)(\%) } & \multicolumn{2}{c}{ Share of Global (Inward)FDI(\%) } \\
\cline { 2 - 5 } & China & India & China & India \\
\hline 2001 & 4.10 & 0.76 & 6.09 & 0.75 \\
2002 & 4.77 & 0.83 & 7.84 & 0.89 \\
2003 & 5.62 & 0.87 & 8.25 & 0.76 \\
2004 & 6.23 & 0.94 & 7.68 & 0.81 \\
2005 & 6.76 & 1.15 & 7.54 & 0.53 \\
2006 & 7.24 & 1.23 & 7.33 & 1.18 \\
2007 & 7.79 & 1.31 & 6.33 & 1.02 \\
2008 & 7.91 & 1.54 & 7.81 & 1.98 \\
2009 & 8.85 & 1.78 & 8.01 & 3.08 \\
2010 & 9.78 & 1.88 & 8.64 & 1.97 \\
2011 & 10.12 & 2.12 & 7.93 & 1.95 \\
2012 & 11.8 & 1.50 & 8.63 & 1.72 \\
2013 & 12.00 & 2.00 & 8.45 & 1.92 \\
2014 & 11.30 & 2.05 & 10.46 & 2.80 \\
\hline
\end{tabular}

Notes: IM denotes imports, EX denotes exports.

The foreign GDP growth has a significantly positive effect on AD use for China but has no significant effect for India. This finding differs from Bown and Crowley (2013). We offer two possible explanations. One explanation for the difference between China and India is that, compared to India, China is more deeply integrated into the world economy (see Table 3) and more influenced by its dependence on the world economy. Another explanation is related to a specific aspect of globalization. Gawande et al. (2011) study the determinants of trade policy responses to the 2008 financial crisis and find that vertical specialization (global fragmentation) is the most powerful economic factor determining trade policy responses. They also find that there is heterogeneity of countries' behavior in their trade policies: it is the demand of vertically specialized domestic exporters that curbed protectionism in some countries including China. India, meanwhile, like some other countries, is influenced by demand from vertically specialized foreign exporters dependent on Indian inputs. Domestic currency appreciation has a significantly positive effect on AD filings both for China and for India. The import penetration ratio has a significantly positive impact on $\mathrm{AD}$ initiation but does not have a significant effect on AD cases for India; as 
for China, it has a significantly positive effect both for $\mathrm{AD}$ initiation and $\mathrm{AD}$ cases in the model without a country fixed effect, but such an effect disappears once controlling for the country fixed effect.

Both the tit-for-tat and general retaliation effect are positive in China but negative in India, though it is only significant in certain specifications. This suggests that the retaliatory pattern of $\mathrm{AD}$ actions by China is different from that of India. As a new $\mathrm{AD}$ user, China will retaliate against $\mathrm{AD}$ actions targeting it. However, India's retaliatory pattern is more similar to that of traditional users. Bao and Qiu (2011) find that retaliation has a negative effect on US AD filings, which mirrors what we have found in the case of India. An increase in AD use against each country in the previous year leads to fewer AD being initiated by each of them due to the threat of retaliation. The similarity between India and traditional AD users may be related to India's large stock of AD cases and relatively high frequency of $\mathrm{AD}$ filings, features that recall traditional users' $\mathrm{AD}$ patterns. There is significant echo effect but no significant deflection effect in China's AD filing. This indicates that when a country receives AD filings from other country, China tends to launch its own filing against that country due to strategic consideration or information transmission. As for India, both echo and deflection effects are significant without country fix effect. The latter effect indicates that India also takes more AD against a country due to trade diversion caused by $\mathrm{AD}$ by a third country. Lastly, the AD club effect is only significant for China when the country effects are controlled for.The number of FTAs' effect on AD filings is negative for China while it is positive for India. This suggests that FTAs help to reduce the use of AD to accomplish the purpose of free trade for China, while India is more likely to protect domestic industries due to facing more imports from FTAs partners. We find that AD filings in China are consistent with the theoretical predictions of increasing trade protectionism during economic recessions, while the 2008 economic recession had the opposite effect on AD filings by India.

\section{Significance test of difference}

The baseline estimates suggest some similarities and differences between what drives AD filings for China and India. We find that some variables (tariff rate, foreign GDP growth and echo effect) only have significant effects on one country, while others (retaliation, FTA and the recession) have significant effects but with different signs. Furthermore, for some variables (domestic GDP growth, industrial structure, trade dependence, real exchange rate and import penetration) we identify common effects but with different magnitudes between the two countries. In order to investigate whether the differences are statistically significant, we pool the data for China and India and run the following regression:

$$
A D_{i j t}=\delta_{0}+A^{\prime} X+\text { Sindia }+B^{\prime} X * \text { india }
$$

The explanatory variables, vector $X$, are as in our baseline regression model and the dummy variable india takes a value of 1 for India and 0 for China. To find whether the coefficients of 
explanatory variables for China's AD filings are significantly different from those for India's, we test the null hypothesis $\mathrm{H} 0$ : $\mathrm{b}_{\text {China }}=\mathrm{b}_{\text {India }}$, with $\mathrm{b}_{\text {China }}=\mathrm{A}$ and $\mathrm{b}_{\text {India }}=\mathrm{A}+\mathrm{B}$ in this model. The results of this test are reported in Table 4.

Table 4.Results of Test of Coefficient Differences

\begin{tabular}{|c|c|c|c|c|}
\hline \multicolumn{2}{|c|}{ Variables } & China & India & Pooled \\
\hline \multirow{7}{*}{$\begin{array}{l}\text { Macroeconomic } \\
\text { Variables }\end{array}$} & $\mathrm{GDP}_{\mathrm{it}-1}$ & - & - & $\mathrm{Y}$ \\
\hline & $\mathrm{TAR}_{\mathrm{it}-1}$ & ns & - & $\mathrm{N}$ \\
\hline & $\mathrm{STR}_{\mathrm{it}}$ & - & - & $\mathrm{N}$ \\
\hline & $\mathrm{DEP}_{\text {it }}$ & + & + & $\mathrm{Y}$ \\
\hline & $\mathrm{FGDP}_{\mathrm{jt}-1}$ & + & $\mathrm{ns}$ & $\mathrm{Y}$ \\
\hline & $\mathrm{EX}_{\mathrm{ijt}-1}$ & + & + & $\mathrm{N}$ \\
\hline & $\mathrm{IMP}_{\mathrm{ijt}}$ & + & + & $\mathrm{N}$ \\
\hline \multirow{5}{*}{$\begin{array}{l}\text { Strategic } \\
\text { Variables }\end{array}$} & TFT $_{\mathrm{ijt}-1}$ & $+(\mathrm{ns})$ & ns & $\mathrm{N}$ \\
\hline & $\mathrm{RET}_{\mathrm{it}-1}$ & $+(\mathrm{ns})$ & - & $\mathrm{Y}$ \\
\hline & CLUB $_{\mathrm{jt}-1}$ & - & + & $\mathrm{Y}$ \\
\hline & $\mathrm{DEFL}_{\mathrm{jt}-1}$ & ns & + & $\mathrm{Y}$ \\
\hline & $\mathrm{ECHO}_{\mathrm{jt}}$ & + & $+(\mathrm{ns})$ & $\mathrm{Y}$ \\
\hline Other & FTA $_{\text {it }}$ & - & + & $\mathrm{Y}$ \\
\hline Variables & $\mathrm{REC}_{\mathrm{t}}$ & + & - & $\mathrm{Y}$ \\
\hline
\end{tabular}

According to the test results, there are significant differences both in terms of the magnitude and the sign of specific coefficients between the estimated models for the two countries. First, we focus on the differences in the magnitude. For GDP growth, the effect on China is greater than on India. The significantly negative effect of GDP growth may partly explain why ADs initiated by China are much fewer than by India. China experienced the fastest growth among the major economies in the world over the period of anlysis, while India grew more slowly and with more fluctuation (see Figure 2 and Figure 3). As for the greater positive effect of trade dependence on China, a possible explanation is that the trade ratio for China is much higher than for India (see Table 1) and therefore AD use by China was more sensitive to the change in trade dependence.

As for the differences in sign, except for general retaliation as mentioned above, there are two other variables, i.e. FTA and recession, the coefficients on which have opposite signs. The significantly negative FTA effect for China and significantly positive effect for India could be explained as follows. On the one hand, India already participates in more FTAs than China so the positive marginal effect is diminishing for India. On the other hand, it reflects the fact that China is increasingly engaging in trading partnerships through FTAs and is therefore reducing AD use as it actively expands the number and scope of FTAs. The positive effect of 2008 economic recession 
on AD filings for China is consistent with our expectation. However, the effect of recession for India is significantly negative. This can be explained by the previous finding that India's AD use is negatively associated with retaliation. Since 2008, the economic growth of many countries has slowed down and therefore have been more likely to adopt protectionist policies which leads to fewer AD being initiated by India due to the threat of retaliation.

Comparative analysis of $A D$ defendants across target countries

Table 5.Results of Estimates for Developed and Developing Target Countries

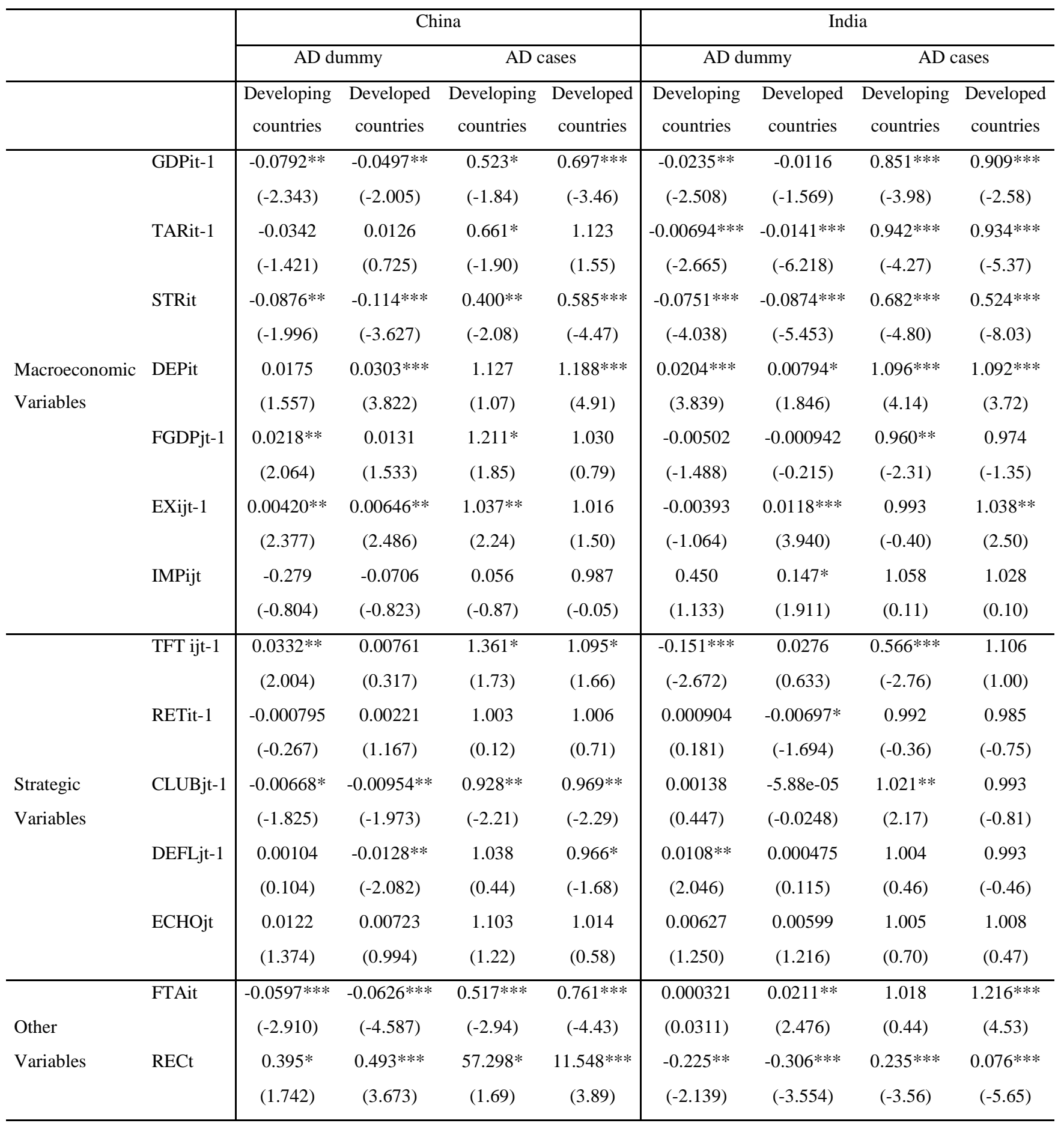




\begin{tabular}{|c|c|c|c|c|c|c|c|c|}
\hline Country fixed effect & Yes & Yes & Yes & Yes & Yes & Yes & Yes & Yes \\
\hline \multirow{2}{*}{ Regression method } & \multirow{2}{*}{ Probit } & \multirow{2}{*}{ Probit } & Negative & Negative & \multirow{2}{*}{ Probit } & \multirow{2}{*}{ Probit } & Negative & Negative \\
\hline & & & Binomial & Binomial & & & Binomial & Binomial \\
\hline Observations & 177 & 301 & 177 & 301 & 526 & 734 & 526 & 749 \\
\hline
\end{tabular}

We now investigate whether China and India treat target countries differently, and disaggregate our sample between developed and developing countries in the target populations. The results of these estimations are reported in Table 5.

In terms of the macroeconomic perspective, the main differences are found for trade dependence and foreign GDP growth in China's AD against developed and developing countries. Trade dependence and foreign GDP have significantly positive effects for both developed and developing countries. The reason for the former is that China faces strong import pressure from developed countries, against which its $\mathrm{AD}$ actions are mainly targeted (the number of AD against developed countries is twice that against developing countries). The reason for the latter is that China's exports are mainly low quality manufacturing products, which means the China's products tend to be similar and engage in export competition with products from developing countries. Compared to China, India's filings against developed and developing countries are less discriminatory, which is also reflected in the fact that there are no developed or developing countries which India systematically targets. In the regression with sub samples, there is more solid evidence that the AD pattern of India is less regular, containing more random features.

Although differences exist in terms of the strategic patterns between China and India, for both countries the strategic effects with respect to developing countries are more significant. The tit-for-tat retaliation and club effects are the main strategic motivation for China and these two effects are more significant when targeting developing countries. To some extent, this reflects increasingly how more developing countries than developed countries tend to be defendants of $\mathrm{AD}$ cases. In global $\mathrm{AD}$ proliferation, developing countries are not only replacing developed countries to be the major initiators, but are also becoming the major targets of AD use. Disputes between developing countries are also on the rise (Bao, 2012).

Participation in FTAs reduces AD filings against developed and developing countries by China. Meanwhile, for India FTA participation increases its filings against developed countries but has no significant effect when it comes to developing countries. As for the 2008 economic recession, while China's filings increase consistently across the board, India reduces cases against developing countries but increases cases against developed countries.

\section{Endogeneity issues and robustness checks}

We need to consider whether our findings are affected by any endogeneity issues. We have used a 1-year lag for the main macroeconomic economic variables, i.e. domestic GDP growth rate, 
foreign GDP growth rate, real exchange rate and weighted average tariff rate, which should help to attenuate any potential endogeneity problem. As for the endogenous choice of targeted countries, we employ specifications both with and without country fixed effects. We also disaggregate our sample on country-industry (HS2) level to investigate whether China and India use $\mathrm{AD}$ differently across industries, and control for industry fixed effects (see Table 6). Additionally, we consider whether there are some possible omitted variables such as China's accession into the WTO which are affecting the results, but we find that they are insignificant and make no difference to our results.

In the comparative analysis of $\mathrm{AD}$ patterns and the significance test of difference, we use appropriate models (probit model for binary variables and count model for count variables)both with and without country fixed effect to run the regressions and obtain similar results, which shows that our results are generally robust. For further robustness checks, we adjust model (1) by replacing the dependent variable with the number of product categories involved in $\mathrm{AD}$ cases. $\mathrm{We}$ use this alternative dependent variable because, on the one hand, the number of $\mathrm{AD}$ each year is limited and, on the other, the products involved in $\mathrm{AD}$ are generally from more than one category. Given that products are classified in the Global Antidumping Database into HS6 for some cases and HS8 for others, we classify the products by HS6 to maintain consistency. Regression results based on the new model are reported in Table 7.

Table 6. Results for Comparative Analysis with Country-Industry Level Data

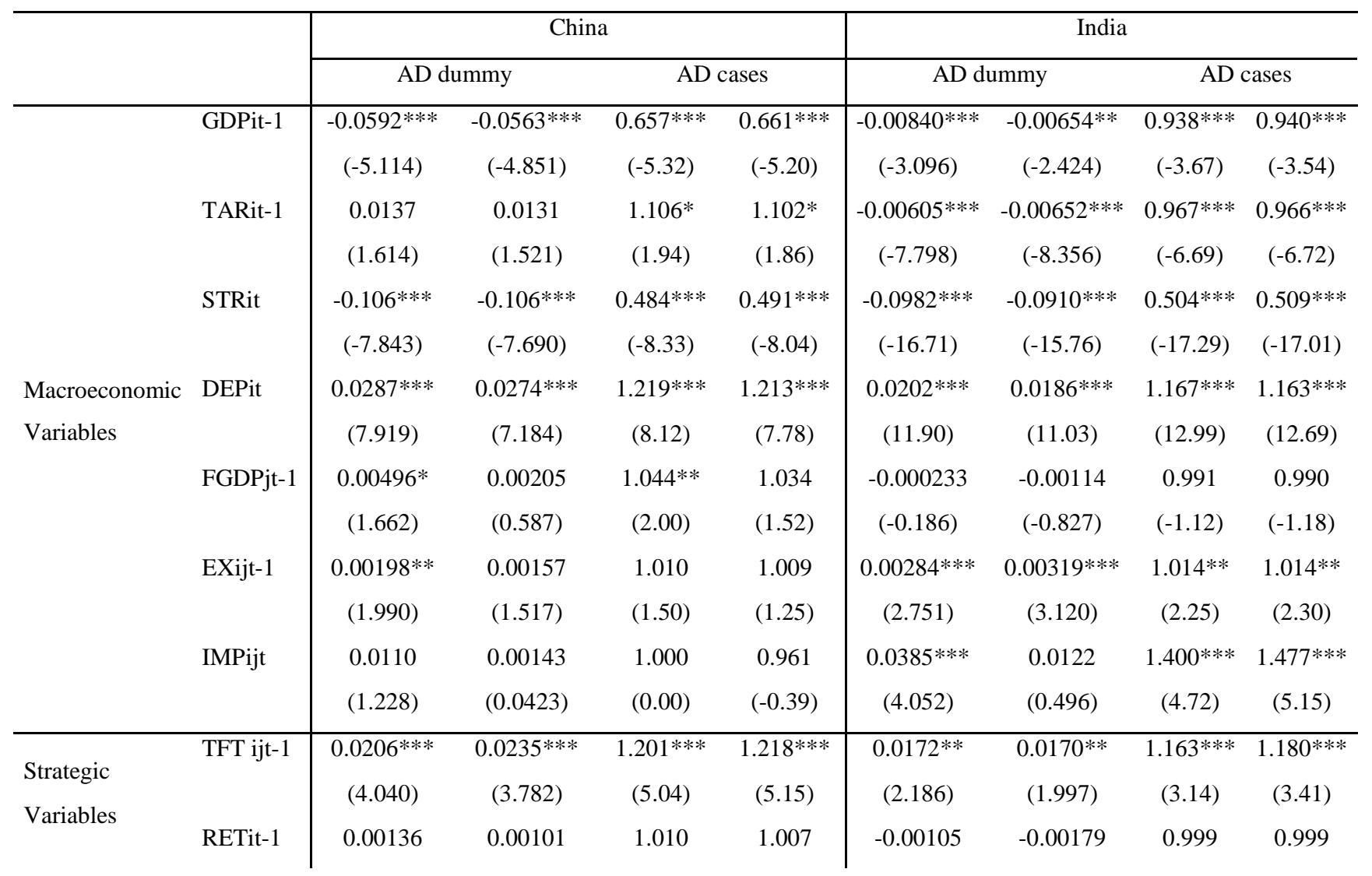




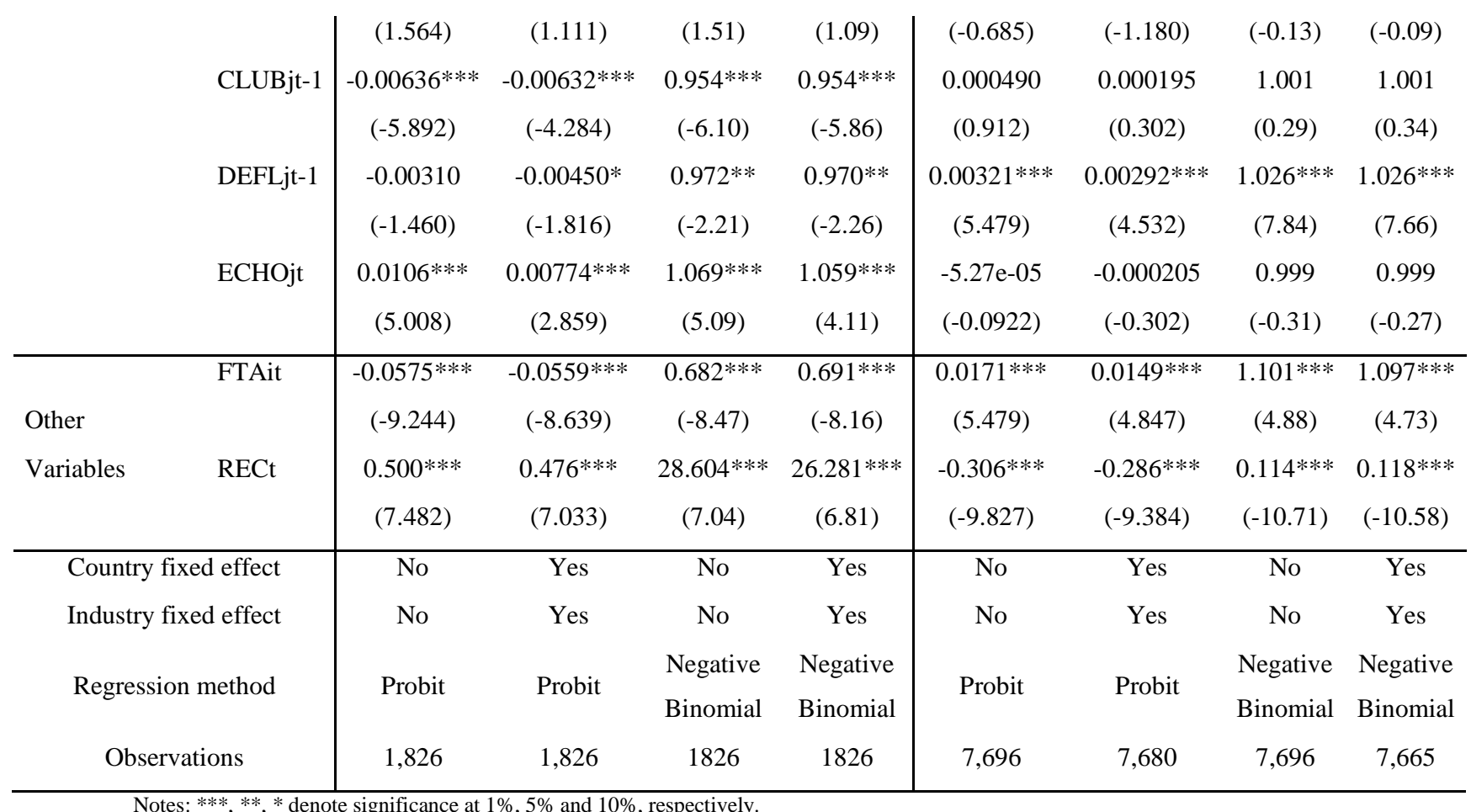

By comparing the results in Table 2 with Table 6, we find that there are some differences between the country level and country-industry level analysis for China and basically no differences for India. For India, the sign and the significance of all the variables is largely unchanged with the exception of the tit-for-tat retaliation variable, which becomes significantly positive in the new model. The intuition for the change is straightforward: tit-for-tat retaliation in India is different across industries and therefore the positive effect dominates when we examine the total effect at the country level. The results for China are robust in general, though the significance of some macroeconomic variables (foreign GDP, real exchange rate and import penetration) become insignificant especially with industry fixed effects controlled for, while some strategic variables (tit-for-tat retaliation and AD club effect) become more significant. The former shows the effect of these variables disappears when considering them at the industry level. The latter suggests that the strategic consideration is more sensitive in specific industries. Carefully comparing the new results in Table 7 with those in Table 2 and Table 6, we find our results are quite robust. The signs of all variables and the significance of most variables are unchanged.

Table 7. Results for Comparative Analysis with Product-level data

\begin{tabular}{|c|c|c|c|c|c|c|c|c|c|}
\hline & \multicolumn{4}{|c|}{ China } & \multicolumn{4}{|c|}{ India } \\
\hline & & \multicolumn{4}{|c|}{ Products involved in AD cases } & \multicolumn{4}{|c|}{ Products involved in AD cases } \\
\hline \multirow{5}{*}{$\begin{array}{l}\text { Macroeconomic } \\
\text { Variables }\end{array}$} & GDPit-1 & $0.692^{* * * *}$ & $0.715^{* * *}$ & $0.657^{* * *}$ & $0.661^{* * * *}$ & $0.936^{*}$ & $0.937^{*}$ & $0.938^{* * *}$ & $0.940^{* * * *}$ \\
\hline & & $(-3.06)$ & $(-2.80)$ & $(-5.32)$ & $(-5.20)$ & $(-1.82)$ & $(-1.77)$ & $(-3.67)$ & $(-3.54)$ \\
\hline & TARit-1 & 1.019 & 1.006 & $1.106^{*}$ & $1.102^{*}$ & $0.942^{* * *}$ & $0.942^{* * *}$ & $0.967^{* * * *}$ & $0.966^{* * *}$ \\
\hline & & $(0.23)$ & $(0.07)$ & $(1.94)$ & $(1.86)$ & $(-5.24)$ & $(-5.23)$ & $(-6.69)$ & $(-6.72)$ \\
\hline & STRit & $0.609^{* * *}$ & $0.643^{* * *}$ & $0.484^{* * *}$ & $0.491^{* * *}$ & $0.668^{* * * *}$ & $0.670^{* * *}$ & $0.504^{* * *}$ & $0.509^{* * *}$ \\
\hline
\end{tabular}




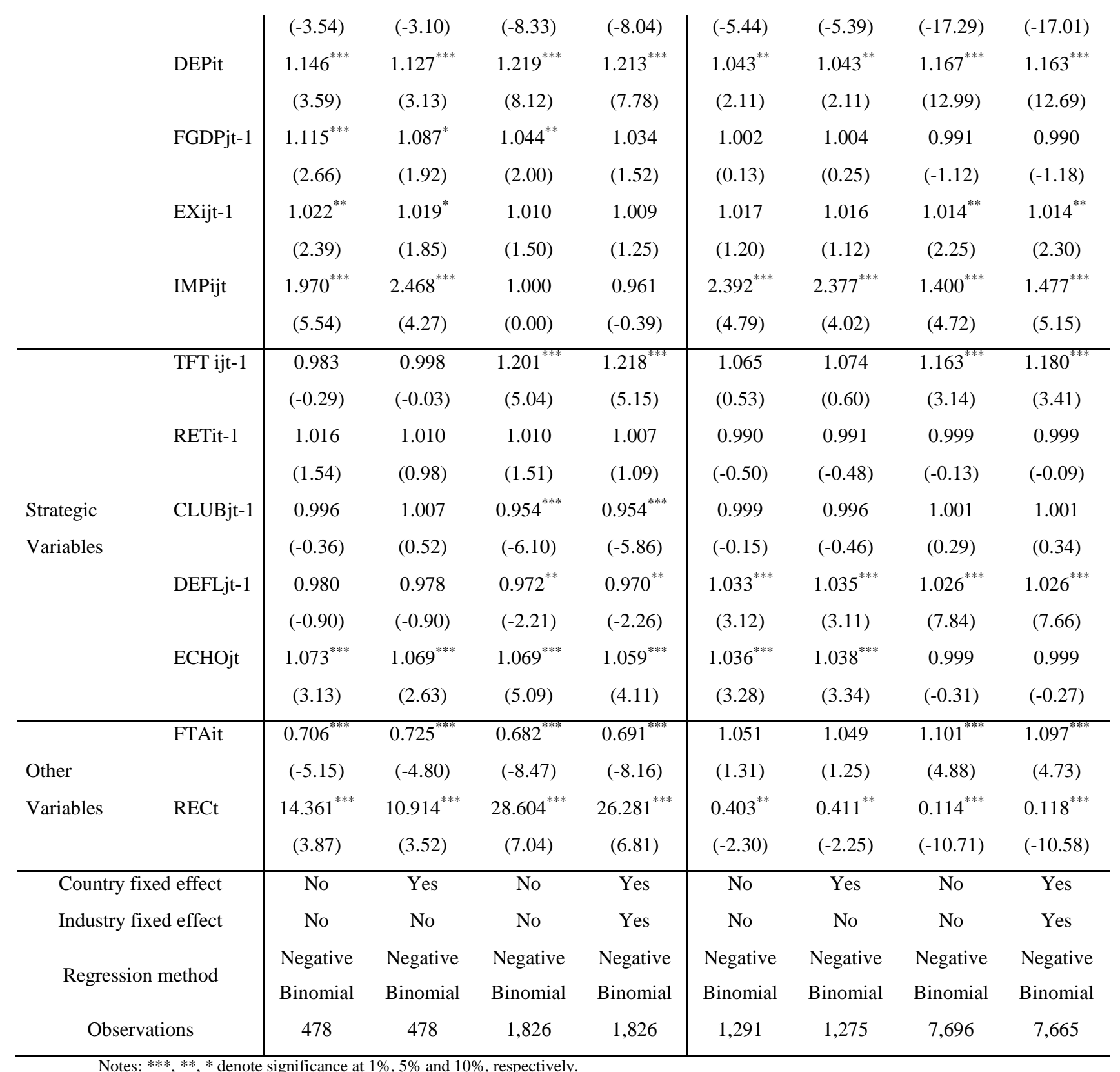

\section{Conclusions}

This paper aims to explain the differences in AD patterns in the cases of China and India from the perspective of looking at various determinants of $\mathrm{AD}$ use, which are broadly classified into three categories: macroeconomic, strategic and other determinants. We find evidence of systematic influences on Chinas AD filings, except for the unexpected, positive effect of foreign GDP growth, which may be attributed to globalization effects. Compared to China, AD use by India displays less systematic features, especially in terms of strategic factors.

We also find that $\mathrm{AD}$ filings in Chinas case are more constrained by economic growth, the $\mathrm{AD}$ club effect and FTA participation, which may partly explain why China initiates fewer AD filings than India. Meanwhile, AD use by China is also influenced less significantly by some positive 
effects and more significantly by some negative effects which vary across industries. But such differences across industries do not exist in the case of India. Differences also exist between the two countries in the retaliatory and contagion patterns of AD filings. Interestingly, India' $\mathrm{s}$ retaliatory pattern is more similar to that of the developed countries.

In terms of $\mathrm{AD}$ targets, China's $\mathrm{AD}$ filings target developed countries more than developing countries, especially before the recession, while India targets developing countries somewhat more than developed countries. The present, positive analysis of differences and similarities in the drivers of $\mathrm{AD}$ provides no basis, however, for drawing normative implications or conclusions about the relative desirability or effectiveness of AD policies in the two countries. Policy makers in the two countries may well be interested know, nevertheless, how their own use of $\mathrm{AD}$ measures differs from that of another major and increasingly outward-oriented developing country. Indeed, trade policy makers in the trading partners (current and potential targets of $\mathrm{AD}$ measures) of both China and India may well interested also knowing how and why AD use differs in the two countries.

\section{References:}

Aggarwal, Aradhna (2004) Macro Economic Determinants of Antidumping: A Comparative Analysis of Developed and Developing Countries, World Development, 32, 1043-57

Ahn, Dukgeun and ShinWonkyu (2011) Analysis of Anti-Dumping Use in Free Trade Agreements, Journal of World Trade, 45, 431-56.

Bagwell, Kyle and Robert Staiger (2003) Protection and the Business Cycle, Advances in Economic Analysis and Policy, 3, 1 -43.

Bagwell, Kyle and Robert Staiger (1990) A Theory of Managed Trade, American Economic Review, 80, 779-95.

Bao, Xiaohua and Larry Qiu (2011) Is China's Antidumping More Retaliatory than that of the US? Review of International Economics, 2, 374-89.

Bao,Xiaohua (2011) Has China Faced Discriminative Antidumping? Management World (in Chinese), 3, 32-43.

Bao,Xiaohua (2012) Why Global Antidumping Grows: a Study on Antidumping Motivation and 'North-South' Differences, Economic Management (in Chinese), 34, 10-21.

Baruah, N.andana (2007) An Analysis of Factors Influencing the Antidumping Behavior in India", The World Economy, 30, 1170-1191.

Blonigen, Bruce and Chad Bown (2003) Antidumping and Retaliation Threats, Journal of International Economics ,60, 249-73.

Blonigen, Bruce (2006)Working the System, Firm Learning and the Antidumping Process, European Journal of Political Economy, 22, 715-31..

Bown, Chad (2012) Global Antidumping Database, http://econ.worldbank.org/ttbd/gad/

Bown, Chad and Meredith Crowley (2006) Policy Externalities: How U.S. Antidumping Affects Japanese Exports to the EU, European Journal of Political Economy, 22, 696-14. 
Bown, Chad and Meredith Crowley (2013) Import Protection, Business Cycles, and Exchange Rates: Evidence from the Great Recession, Journal of International Economics, 90, 50-64.

Bown, Chad and Meredith Crowley (2014) Emerging Economics, Trade Policy and Macroeconomic Shocks, Journal of Development Economics, 111, 261-73..

Bown, Chad and Patricia Tovar (2011) Trade Liberalization, Antidumping, and Safeguards: Evidence from India's Tariff Reform, Journal of Development Economics, 96, 115-25.

Crowley, Meredith (2010) Split Decisions in Antidumping Cases, B.E. Journal of Economic Analysis and Policy,10, 1935-82

Dong, Baomin (2013) Cost-Based Anti-dumping As A Repeated Game, Economic Record, 89, $95-105$.

Feinberg, Robert (2005) U.S. Antidumping Enforcement and Macroeconomic Indicators Revisited: Do Petitioners Learn?, Review of World Economics, 141, 612-22.

Feinberg, Robert,1989, Exchange Rates and Unfair Trade, Review of Economics and Statistics, 71, 704-07.

Feinberg, Robert and Kara Reynolds (2006) The Spread of Antidumping Regimes and the Role of Retaliation in Filings, Southern Economic Journal, 72, 877-90.

Finger, Michael and Julio Nogués (eds) (2005) Safeguards and Antidumping in Latin American Trade Liberalization: Fighting Fire with Fire, New York: Palgrave.

Francois, Joseph and Gunnar Niels (2006) Business Cycles, the Exchange Rate, and Demand for Antidumping Protection in Mexico, Review of Development Economics, 10, 388-99.

Gawande K, Hoekman B, Cui Y (2011). Determinants of Trade Policy Responses to the 2008 Financial Crisis. World Bank Policy Research Working Paper Series, WPS5862

Irwin, Douglas (2005)The Rise of US Antidumping Activity in Historical Perspective", The World Economy, 28, 651-68.

Knetter, Michael and Thomas Prusa (2003) Macroeconomic Factors and Antidumping Filings: Evidence from Four Countries, Journal of International Economics, 61, 1-17..

Leidy, Michael (1997) Macroeconomic Conditions and Pressures for Protection under Antidumping and Countervailing Duty Laws: Empirical Evidence from the United States, International Monetary Fund Staff Paper, 44(1).

Mah,Jai and Yongdae Kim (2006)Antidumping Duties and Macroeconomic Variables: The Case of Korea, Journal of Policy Modeling, 28,157-62.

Moore, Michael, and Maurizio Zanardi (2009) Does Antidumping Use Contribute to Trade Liberalization in Developing Countries?, Canadian Journal of Economics, 42, 469-95.

Moore, Michael, and Maurizio Zanardi (2011) Trade Liberalization and Antidumping: Is There a Substitution Effect?", Review of Development Economics, 1, 601-19.

Niels, Gunnar and Joseph Francois (2006) Business Cycles, the Exchange Rate and Demand for Antidumping Protection in Mexico, Review of Development Economics, 10, 388-99.

Prusa, Thomas and Susan Skeath (2002) The Economic and Strategic Motives for Antidumping Filings, Review of World Economics, 138, 389-413.

Prusa, Thomas and Susan Skeath (2004), Modern Commercial Policy: Managed Trade or Retaliation?, in James Hartigan (ed), Handbook of International Economics, Vol. II , London: Blackwell. 
Sadni-Jallab, Mustapha, Monnet Gbakou and Rene Sandretto (2006) Antidumping Procedures and Macroeconomic Factors: A Comparison between the United States and the European Union, Global Economic Journal, 6, 1-22.

Vandenbussche, Hylke and Maurizio Zanardi (2008) What Explains the Proliferation of Antidumping Laws, Economic Policy, 23, 98-103.

Wang,Xiaosong and ShexiangXie (2009) Why on Earth Does China Face Antidumping?Management World (in Chinese), 12, 27-38.

Yang, Xiaoyun and Zhaocheng Yao (2012)A Contrastive Study on Chinese and Indian Antidumping Behavior, Journal of International Trade (in Chinese), 7, 132-39.

Zeng, Ka (2011) The Political Economy of Developing Country Antidumping Investigations against China, International Interactions, 37, 190-214.

Zhang, Yan and Jianguo, Xie (2011) Do Regional Trade Agreements Decrease Members' Antidumping Threat: an Analysis of Chinese Experience, Journal of International Trade (in Chinese), 8,30-39.

\section{Appendix:}

Table A1. Industries Targeted by China and India

\begin{tabular}{|c|c|c|c|c|c|}
\hline \multirow[b]{2}{*}{ HS2 } & \multirow[b]{2}{*}{ Industry (product group) } & \multicolumn{2}{|r|}{ China } & \multicolumn{2}{|r|}{ India } \\
\hline & & $\begin{array}{l}\mathrm{AD} \\
\text { cases }\end{array}$ & $\begin{array}{l}\text { Products (HS6) } \\
\text { involved }\end{array}$ & $\begin{array}{l}\mathrm{AD} \\
\text { cases }\end{array}$ & $\begin{array}{l}\text { Products (HS6) } \\
\text { involved }\end{array}$ \\
\hline 02 & Meat and edible meat offal & 4 & 5 & 0 & 0 \\
\hline 04 & $\begin{array}{l}\text { Dairy prod; birds' eggs; natural honey; } \\
\text { edible }\end{array}$ & 0 & 0 & 1 & 1 \\
\hline 05 & $\begin{array}{l}\text { Products of animal origin, nes or } \\
\text { included. }\end{array}$ & 1 & 5 & 0 & 0 \\
\hline 11 & $\begin{array}{l}\text { Prod.mill.indust; malt; } \quad \text { starches; } \\
\text { inulin; wheat g }\end{array}$ & 1 & 1 & 0 & 0 \\
\hline 22 & Beverages, spirits and vinegar. & 3 & 3 & 0 & 0 \\
\hline 23 & $\begin{array}{l}\text { Residues \& waste from the food indust; } \\
\text { prepr ani }\end{array}$ & 1 & 4 & 9 & 55 \\
\hline 25 & $\begin{array}{l}\text { Salt; sulphur; earth \& ston; plastering } \\
\text { mat; lime }\end{array}$ & 0 & 0 & 4 & 11 \\
\hline 27 & $\begin{array}{l}\text { Mineral fuels, oils \& product of their } \\
\text { distill }\end{array}$ & 0 & 0 & 10 & 39 \\
\hline 28 & $\begin{array}{l}\text { Inorgn chem; compds of prec } \mathrm{mtl} \text {, } \\
\text { radioact element }\end{array}$ & 7 & 17 & 114 & 235 \\
\hline 29 & Organic chemicals. & 128 & 163 & 281 & 371 \\
\hline 31 & Fertilisers. & 0 & 0 & 6 & 16 \\
\hline 32 & $\begin{array}{l}\text { Tanning/dyeing extract; tannins \& } \\
\text { derivs; pigm et }\end{array}$ & 0 & 0 & 11 & 26 \\
\hline 37 & Photographic or cinematographic goods. & 9 & 8 & 27 & 40 \\
\hline 38 & Miscellaneous chemical products. & 11 & 37 & 22 & 44 \\
\hline 39 & Plastics and articles thereof. & 25 & 65 & 123 & 216 \\
\hline 40 & Rubber and articles thereof. & 9 & 34 & 38 & 92 \\
\hline 44 & $\begin{array}{l}\text { Wood and articles of wood; wood } \\
\text { charcoal. }\end{array}$ & 0 & 0 & 9 & 35 \\
\hline 47 & Pulp of wood/of other fibrous cellulosic & 9 & 5 & 0 & 0 \\
\hline
\end{tabular}




\begin{tabular}{|c|c|c|c|c|c|}
\hline 48 & $\begin{array}{l}\text { mat; } \\
\text { Paper \& paperboard; art of paper pulp, } \\
\text { paper/p }\end{array}$ & 34 & 37 & 24 & 42 \\
\hline 50 & Silk. & 0 & 0 & 5 & 21 \\
\hline 53 & $\begin{array}{l}\text { Other vegetable textile fibres; paper } \\
\text { yarn \& w }\end{array}$ & 0 & 0 & 2 & 14 \\
\hline 54 & Man-made filaments. & 12 & 14 & 36 & 47 \\
\hline 55 & Man-made staple fibres. & 2 & 3 & 42 & 79 \\
\hline 56 & $\begin{array}{l}\text { Wadding, felt \& nonwoven; yarns; } \\
\text { twine, cordage, }\end{array}$ & 0 & 0 & 5 & 10 \\
\hline 58 & $\begin{array}{l}\text { Special woven fab; tufted tex fab; lace; } \\
\text { tapes }\end{array}$ & 0 & 0 & 2 & 10 \\
\hline 59 & $\begin{array}{l}\text { Impregnated, coated, cover/laminated } \\
\text { textile fabr }\end{array}$ & 0 & 0 & 8 & 19 \\
\hline 64 & $\begin{array}{l}\text { Footwear, gaiters and the like; parts of } \\
\text { such }\end{array}$ & 0 & 0 & 4 & 6 \\
\hline 68 & $\begin{array}{l}\text { Art of stone, plaster, cement, asbestos, } \\
\mathrm{mica} / \mathrm{sim}\end{array}$ & 0 & 0 & 22 & 19 \\
\hline 69 & Ceramic products. & 0 & 0 & 7 & 23 \\
\hline 70 & Glass and glassware. & 2 & 4 & 39 & 33 \\
\hline 72 & Iron and steel. & 77 & 26 & 354 & 163 \\
\hline 73 & Articles of iron or steel. & 19 & 12 & 16 & 52 \\
\hline 74 & Copper and articles thereof. & 0 & 0 & 7 & 24 \\
\hline 76 & Aluminium and articles thereof. & 0 & 0 & 14 & 36 \\
\hline 81 & $\begin{array}{l}\text { Other base metals; cermets; articles } \\
\text { thereof. }\end{array}$ & 0 & 0 & 2 & 5 \\
\hline 84 & $\begin{array}{l}\text { Nuclear reactors, boilers, mchy \& mech } \\
\text { appliance; }\end{array}$ & 0 & 0 & 42 & 125 \\
\hline 85 & $\begin{array}{l}\text { Electrical mchy equip parts thereof; } \\
\text { sound record }\end{array}$ & 0 & 0 & 101 & 144 \\
\hline 87 & $\begin{array}{l}\text { Vehicles o/t railw/tramw roll-stock, pts } \\
\& \text { access }\end{array}$ & 5 & 5 & 7 & 28 \\
\hline 90 & $\begin{array}{l}\text { Optical, photo, cine, meas, checking, } \\
\text { precision }\end{array}$ & 12 & 27 & 8 & 24 \\
\hline
\end{tabular}

